\title{
Low MW Peptides and Carcinogenesis
}

\author{
Gianfranceschi GL ${ }^{1}$ and Reichelt $\mathrm{KL}^{2}, 3^{*}$ \\ ${ }^{1}$ Centro Studi "Giuseppe Gianfranceschi" 60031, Castelplanio (AN), Italy \\ ${ }^{2,3}$ Kleve 4541, University of Oslo, Lab 1, No-1337, Sandvika, Norway
}

*Corresponding author: Reichelt KL, Lab 1, No-1337, Sandvika and Kleve 4541, University of Oslo, No-00 37, Oslo, Norway, Tel: +47 21 0635 57; E-mail: karlr@ulrik.uio.no

Received date: March 30, 2015; Accepted date: May 21, 2015; Published date: May 27, 2015

Copyright: ( 2015 Gianfranceschi, et al. This is an open-access article distributed under the terms of the Creative Commons Attribution License, which permits unrestricted use, distribution, and reproduction in any medium, provided the original author and source are credited.

\section{Abstract}

Problem: Low MW peptides many of them N-substituted, have growth inhibitory effects. Are the peptide levels different in malignant cells from normal cells?

Method: Deprimerones dissociated from DNA at pH 9.5 was measured in normal and malignant cells. The level of Low MW compounds was also compared to large MW compounds [ratios] after gel filtration.

Result: Chalones and some other low MW compounds were not as in normal tissues and cells found in these. However, these peptides could be found in the incubation fluid or ascites. DNA bound peptides were decreased in malignant cells.

Keywords: Peptide; Transcription; Inhibition; Differentiation; Carcinogenesis

\section{Introduction}

Chalones [1] are endogenous growth inhibiting factors with reversible and relative tissue specific effects. Purification however, was initially not successful, and we now know that this was due to low MW peptides binding to different protein molecules and other macromolecules depending on concentration of salts, $\mathrm{pH}$ etc. Peptides easily bind to larger molecules and each other [2]. Deprimerones also peptides, bind to DNA [3]. Chalones and deprimerones are all $\mathrm{N}$ substituted (Table 1). They often have bell shaped [hormetic] dose responses and demand extensive testing over a large concentration range. Optimal effects are often in the nano-to pico-molar range. The Chalones and deprimerones are externalized or lost from the cells in malignant states [4-6] and can be purified from ascites [6].

\section{Properties of low MW mitosis inhibitory peptides}

A: They are apparently phosphorylated by protein kinase CKII and can translocate to the nucleus where they bind to DNA [11-13] but not by a covalent bond [14].

B: These peptides cause differentiation when inhibiting mitosis [15-16], which is the opposite of the malignant process.

C: The peptides apparently act by controlling transcription [3,13,17-19].

D: The chalones show bell shaped dose responses with optimal effect from 10-9 to 10-14 M [1]. This phenomenon is known as hormesis.

E: Cyclic AMP is involved since propranolol modifies the effects of epidermal penta-peptide [20]. The colonic tri-peptide also decreases non-tumorigenic colon cells levels of cyclic AMP [21].
F: The epidermal peptide and the hemo- regulating peptide change RNA profiles in target cells [22]. Microarray of oncogenes \pm specific peptide to cultured T cells or colon carcinoma cells [HT29] studied with real time PCR [23-25] points to similar mechanisms. The epidermal pentapeptide inhibits the oncogene c-Fos, ki-ras and Neu m-RNA formation in TC3H10 cells [23]. The Colon tri- peptide caused a considerable increase in Fos antigen [24].

G: Phosphorylation also make the peptides more resistant to peptidase break down [12].

$\mathrm{H}$ : The binding to DNA seems to be divalent cation $\left[\mathrm{Mg}^{2+}, \mathrm{Fe}^{2+}\right.$, $\mathrm{Cu}^{2+}$ ] dependent [18].

I: Different growth inhibitors impede metastases and growth of subcutaneously injected tumors [26-29] and most in the slowly growing clones. The Colon tri-peptide also inhibits cholic acid induced hyperplasia and hypertrophy [30] as well as Trimethylhydrazine induced hyperplasia [31].

J: The peptides "leak out" or are transported out to the medium from malignant cells or tissues compared to normal cells and tissues $[4,5]$. For instance the mammary carcinoma cell inhibitor could be found in the ascites fluid [4-6].

K: Combining the Colon derived tri-peptide with Vitamin A [also a differentiation inducing factor] enhances the effect of the peptide against HT29 considerably [26]. The cancer cells were injected in athymic mice [26] with inhibition of more than $90 \%$.

\begin{tabular}{|l|l|c|}
\hline Epidermal cells & PyroE-E-D-S-GOH and PyroE-GOH & 1 \\
\hline Colon Endothelial cells & PyroE-H-GOH & 1 \\
\hline Hepatocytes & $\begin{array}{l}\text { PyroE-Q-S-G-DNH2, PyroE-Q-S-G-DOH, } \\
\text { Pyro-E-E-S-G-DNH2, PyroE-E-S-G-DOH. }\end{array}$ & 1 \\
\hline Melanocytes & PyroE-F-GNH2 & 1 \\
\hline
\end{tabular}




\begin{tabular}{|l|l|l|}
\hline T-Lymfocytes & AcE-S-GNH2 & 1 \\
\hline Neuroblast cells & AcD-Q-Y-GNH2 & \\
\hline Hemoregulatory peptides & Pyro-E-E-D-C-KOH & 7 \\
& AcS-D-K-POH]. & 8 \\
\hline Thymus factors & pyroE-A-E-S-N; & 9 \\
& PyroE-A-G-G-S-E-D & \\
& PyroE-A-G-E-E-S-N & 1 \\
\hline Seminal plasma & PyroE-A-E-S-A & 0 \\
\hline PyroE=pyroglutamic acid. & PyroE-V-A-D-S-D-Q-N & \\
\hline
\end{tabular}

Table 1: Isolated low MW growth inhibitors of chalonic nature.

\section{Methods}

Deprimerones were isolated from different tissues as described [3] and the peptide released from DNA by alkaline extraction in a bicarbonate buffer at $\mathrm{pH}$ 9.5. Peptide levels are expressed as $\mu \mathrm{g}$ peptides/10 mg DNA.

The following normal tissues were studied: rat Liver, mouse Liver, mouse Thymus and Fibroblast L-929 cells. The malignant cells were Novikoff hepatoma cells, mouse fibrosarcoma, mouse lymphosarcoma and fibrosarcoma LP-59 cells.

Chalones were obtained by immersing tissues or cells in ice-cold water [4], and homogenized in ice. Acetic acid was added to a final concentration of $0.5 \mathrm{M}$ which also inhibits many peptidases. Proteins were separate from low MW compounds by gel filtration on Sephadex G-25 columns in $0.5 \mathrm{M}$ acetic acid.

Aliquots of $0.4 \mathrm{ml}$ each $4 \mathrm{ml}$ fraction were hydrolyzed in $2 \mathrm{M} \mathrm{KOH}$ for 2 hours in a boiling water bath, neutralized with $2 \mathrm{MHCl}$ and ninhydrin color developed as described by Rosen [32] [also tryptophan survives this hydrolysis]. With this method each amino acid has the same molecular absorption coefficient. The following cells and tissues were studied: Normal tissues: Epidermis [Mouse], Epidermis [human], Epidermis [Pig], Colon [Mice], Colon [Human], Liver [Rat], Liver [Mouse], Cortex [Pig], Kidney [Dog], Spleen [Pig] and granulocytes [Human]. Malignant tissues were from epidermal sarcoma [Human], colon carcinoma [Mouse], colon carcinoma [Human], hepatoma [MH1C1, Rat], neuroblastoma [Human], melanoma [Human], Myelogenic leukemia [Human ] [3,4].

The ratio of low MW ninhydrin colorable compounds to the post hydrolysis amino acid content of the protein peak from G-25 was calculated for each experiment.

\section{Results}

A clear cut decrease in DNA binding peptides as well as all post hydrolyses ninhydrin colorable low MW compounds were found in cancer cells and tissues (Tables 2 and 3). The increase growth rate could be stopped by reintroducing the total peptide level to the normal one.

Similarly the level of amino acids and peptides [low MW fraction after G-25 filtration] was significantly reduced in malignant cells and tissues as seen in Table $3[4,5]$.
The inhibitory peptides could be isolated from incubation fluid or ascites, but very low yields or not at all from the malignant cells and tissues $[4,5]$.

\begin{tabular}{|c|c|c|c|c|c|}
\hline Cell type & Peptide level & \pm SEM & $\mathbf{N}$ & compared & $\mathbf{P}$ \\
\hline Novikoff hepatoma & 95 & 18 & 3 & & \\
\hline Rat liver & 179 & 24 & 3 & & \\
\hline Mouse liver & 185 & 10 & 3 & & \\
\hline All normal liver cells & 177.5 & 9.8 & 6 & 1 and 4 & 0.0078 \\
\hline All normal cells & 187.4 & 7.9 & $\begin{array}{l}1 \\
2\end{array}$ & & \\
\hline All malignant cells & 116.8 & 7.0 & $\begin{array}{l}1 \\
2\end{array}$ & 5 and 6 & 0.0001 \\
\hline
\end{tabular}

Table 2: Level of active peptides released at $\mathrm{pH} 9.5$ from DNA.

Peptide level in $\mu \mathrm{G}$ peptide/10 mg DNA. The remaining peptide fraction when added to a concentration of $10 \mu \mathrm{g}$ peptide fraction $/ 5 \mu \mathrm{g}$ DNA inhibits RNA polymerase by approximately $92 \%$.

\begin{tabular}{|l|l|l|l|l|l|}
\hline Cell type & ratio & SD & N & compared & p \\
\hline Malignant tissues & 4.18 & $0-9$ & 20 & & \\
\hline Normal tissues & 0.83 & $0-39$ & 19 & 1 and 2: & $\begin{array}{l}0.00 \\
01\end{array}$ \\
\hline Malignant cells & 4.48 & 1.43 & 9 & & 0.00 \\
\hline Normal cells & 0.17 & 0.48 & 5 & 3 and 4: & 1 \\
\hline All malignant cells/tissues & 4.49 & 0.84 & 40 & & 0.00 \\
\hline All normal cells/tissues & 0.980 & 1.39 & 41 & 5 and 6: & 01 \\
\hline
\end{tabular}

Table 3: Change in Protein/Low MW ratios in normal and malignant cells and tissues.

The table shows the ratio of the protein peak from G 25 divided by the low MW compounds, both measured as post hydrolysis released ninhydrin colored material. The low MW compounds are lost from the transformed and malignant cells investigated by gel-filtration.

\section{Discussion}

Both the deprimerones isolated by the Italian group and the chalones are decreased in malignant cells and tissues compared to normal controls. When the brakes to growth and/or mitosis are removed faster cell growth is to be expected. Cells that have a high mitotic rate more easily turn malignant [33].

If decreased levels of inhibitor are critical then peptidases and proteases that break down these peptides [34] ought to be involved in carcinogenesis. Increased break down of peptides seem to increase tumor growth. Thus increase in membrane associated cathepsin L increases metastasis of melanomas [35]; Increase in cysteine endopeptidase [36], and Cathepsin D in breast cancer [37] indicate such a possibility. Increasing peptide levels by inhibiting break down [38] seem to retard tumor growth. Peptidases and proteases may have 
prognostic value $[39,40]$. Furthermore the more malignant some tumors are the stronger is the out transport from the cell [41,42]

Based on our findings we propose that decrease in peptides and externalization of the same, may be a final common path in carcinogenesis. Is it possible that membrane changes resulting in decreased level of inhibitory peptides and amino acids is the primary lesion in carcinogenesis?? This would fit both the transport or diffusion out of cells and the peptidase data, where increase in peptidase activity promotes malignancy while decrease inhibits tumor growth.

\section{Conclusion}

Low MW peptides that are mitosis inhibitors and differentiation factors are decreased in transformed and malignant tissues and cells. The chalones can be recovered from the growth medium or from ascites fluid. Differentiation decreases with increased growth and mitosis rates. Increased growth rate ought to increase possible mutation rates and possibly carcinogenesis?

\section{References}

1. Elgjo K, Reichelt KL (2004) Chalones: from aqueous extracts to oligopeptides. Cell Cycle 3: 1208-1211.

2. Reichelt KL (2007) Low Molecular weight peptides. In: Lahti A, Oja SS, Schousboe A, Saransaari P (eds.) Handbook of Neurochemistry and Molecular Neurobiology. Amino acids and peptides in the nervous system. Springer, New York, pp. 402-411.

3. Gianfranceschi GL, Hillar M, Chan JT, Amici D (1980) Low molecular weight peptidic fraction in the chromatin from normal and cancer cells: control of transcription. Mol Biol Rep 6: 95-103.

4. Reichelt K, Haakonsen P, Paulsen J, Kornstad R, Elgjo K (1994) Difference in the distribution of low-molecular-weight peptides and amino-acids in normal and malignant-cells and tissues. Oncol Rep 1: 1107-1112.

5. Elgjo K, Reichelt KL (2013) Is there a final common path in malignancies? Med Hypotheses 81: 357-360.

6. Gembitsky D, Popova N, Antokhin A, Podusov Y, Karpets L, et al. (1996) The Ehrlich ascites carcinoma (EAC) contains 300-500 Da inhibitor(s) suppressing DNA synthesis in cultured EAC cells and EAC cell division in tumor-bearing mice. Oncol Rep 3: 333-338.

7. Paukovits WR, Laerum OD (1982) Isolation and synthesis of a hemoregulatory peptide. Z Naturforsch C 37: 1297-1300.

8. Lenfant M (1989) Sequence determination of an inhibitor of hemopoietic pluripotent stem cell proliferation. PNAS (USA) 36: 779-782.

9. Amici D, Bramucci M, Coderoni S, Maccari E, Miano A, et al. (1987) Regulatory activity of DNA binding small peptides on transcription in cell and cell-free systems. Basic Appl Histochem 31: 317-323.

10. Francescato P, Lugaro G, Gianfranceschi GI, De Angelis L, Chillemi F (1997) Purification, sequence determination and synthesis of seminal plasma peptides and synthesis of some of their analogues. J Pept Sci 3: 54-64.

11. Cardellini E, Angiolillo A, Gianfranceschi GL (1995) Phosphorylation of acidic peptides by protein kinase CKII. Physiol Chem Phys Med NMR 27: 363-368.

12. Bramucci M, Miano A, Amici D (1992) Epidermal inhibitory pentapeptide phosphorylated in vitro by calf thymus protein kinase NII is protected from serum enzyme hydrolysis. Biochem Biophys Res Commun 183: 474-480.

13. Gianfranceschi GL, Czerwinski A, Angiolillo A, Marsili V, Castigli E, et al. (1994) Molecular models of small phosphorylated chromatin peptides. Structure-function relationship and regulatory activity on in vitro transcription and on cell growth and differentiation. Peptides 15: 7-13.
14. Juodka B, Pfütz M, Werner D (1991) Chemical and enzymatic analysis of covalent bonds between peptides and chromosomal DNA. Nucleic Acids Res 19: 6391-6398.

15. Elgjo K, Reichelt KL, Hennings H, Michael D, Yuspa SH (1986) Purified epidermal chalone inhibits proliferation and enhances terminal differentiation in cultured mouse epidermal cells. J Invest Dermatol 87: 555-558.

16. Marsili V, Angiolillo A, Gianfranceschi GL (1995) Synthetic octapeptide pyroGlu-Asp-Asp-Ser-Glu.Glu-Asn promotes differentiation in promyelocytes HL-60 cell line. Cell Mol Biol (Noisy-le-grand) 41: 515-23.

17. Gianfranceschi GL, Barra D, Bossa F, Coderoni S, Paparelli M, et al. (1982) Small peptides controlling transcription in vitro are bound to chromatin DNA. Biochim Biophys Acta 699: 138-148.

18. Mancinelli L, Chillemi F, Cardellini E, Marsili V, Giavarini F, et al. (1999) Molecular models of acidic peptides from pea bud chromatin and seminal plasma. Divalent cations-mediated interaction with DNA. Biol Chem 380: 31-40.

19. Angiolillo A, Desgro A, Marsili V, Panara F, Gianfranceschi GL (1993) Synthetic octapeptide pyroGLU-ASP-ASP-SER-ASP-GLU-GLU-ASN controls DNA transcription in vitro by RNA polymerase II. Experientia 49: 902-905.

20. Elgjo K, Reichelt KL (1994) Beta-receptor blockade by propranolol modifies the effect of the inhibitory, endogenous epidermal pentapeptide on epidermal cell flux at the G2-M transition but not at the G1-S transition. Epithelial Cell Biol 3: 32-37.

21. Reichelt WH, Iversen JG, Paulsen JE, Elgjo K, Reichelt KL (2004) Pyroglutamyl-histidyl-.glycine, the endogenous colon mitosis inhibitor, regulates cyclic AMP level in non-tumorigenic colonic epithelial cells. Anticancer Res 24: 1415-1418.

22. Jensen PK, Elgjo K, Laerum OD, Bolund L (1990) Synthetic epidermal pentapeptide and related growth regulatory peptides inhibit proliferation and enhances differentiation of primary and regenerating cultures of human epidermal keratinocytes. J Cell Sci 97: 51-58.

23. Liu Y, Tong $\mathrm{T}$ (1999) The growth-inhibiting epidermal pentapeptide, pyroGlu-glu-asp-ser-GlyOH, inhibits growth and alters gene expression in non-transformed $\mathrm{NC} 3 \mathrm{H} 10$ and transformed $\mathrm{TC} 3 \mathrm{H} 10$ fibroblasts. Oncol Rep 6: 445-449.

24. Reichelt WH, Liu Y, Luna L, Eigjo K, Reichelt KL (2002) Early oncogene mRNA expression in HT-29 cells treated with the endogenous colon mitosis inhibitor pyroglutamyl-histidyl-glycine. Anticancer Res 22: 991-996.

25. Liu Y, Reichelt WH, Luna L, Elgjo K, Reichelt KL (2003) The effects of a growth-inhibiting tripeptide, acetylGlu-Ser-GlyNH2 (Ac-ESG), on gene expression and cell cycle progression of two lymphoma cell lines. Anticancer Res 23: 3159-3165.

26. Paulsen JE, Lützow-Holm C (2000) In Vivo growth inhibition of Human colon carcinoma cells (HT-29) by All-Trans retinoic acid, Difluoromethylornithine and colon mitosis inhibitor, individually and in combination. Anticancer Res 20: 3485-3490.

27. Skraasatd Ö, Reichelt KL (1989) An endogenous colon mitosis inhibitor reduces proliferation of colon carcinoma cells (HT29) in serum-restricted medium. Virchows Arch B 56: 393-396.

28. Paulsen JE, Hall KS, Rugstad HE, Reichelt KL, Elgjo K (1992) The synthetic hepatic peptides pyroglutamylglutamylglycylserylasparagine and pyroglutamylglutamylglycylserylaspartic acid inhibit growth of $\mathrm{MH1C1}$ rat hepatoma cells transplanted into Buffalo rats or athymic mice. Cancer Res 52: 1218-1221.

29. Paulsen JE (1993) The synthetic colon peptide pyroGlu-His-GlyOH inhibits growth of human colon carcinoma cells (HT-29) transplanted subcutaneously into athymic mice. Carcinogenesis 14: 1719-1721.

30. Skraastad O, Reichelt KL (1988) An endogenous colon mitosis inhibitor and dietary calcium inhibit the increased colonic cell proliferation induced by cholic acid. Scand J Gastroenterol 23: 801-807.

31. Skraastad O, Reichelt KL(1989) An endogenous mitosis inhibitor reduces the increased cell proliferation in colonic epithelium induced by dietary 
Citation: Gianfranceschi GL, Reichelt KL (2015) Low MW Peptides and Carcinogenesis. J Carcinog Mutagen 6: 226. doi: 10.4172/2157-2518.1000226

Page 4 of 4

cholic acid and treatment with 1,2-dimethylhydrazine. Carcinogenesis 10: 79-82.

32. ROSEN H (1957) A modified ninhydrin colorimetric analysis for amino acids. Arch Biochem Biophys 67: 10-15.

33. Cohen SM, Ellwein LB (1990) Cell proliferation in carcinogenesis. Science 249: 1007-1911.

34. Bramucci M, Miano A, Quassinti L, Maccari E, Canofeni S, et al. (1996) Purification and characterisation of swine serum proteinase which hydrolyses epidermal inhibitory pentapeptide. Biochim Biophys Acta 1290: 184-190.

35. Rozhin J, Wade RL, Honn KV, Sloane BF (1989) Membrane-associated cathepsin L: a role in metastasis of melanomas. Biochem Biophys Res Commun 164: 556-561.

36. Siewinski M, Gutowicz J, Zarzycki A, Mikulewicz W (1996) Role of cysteine endopeptidases in cancerogenesis. Cancer Biother Radiopharm 11: 169-176.
37. Tedone T, Correale M, Barbarossa G, Casavola V, Paradiso A, et al. (1997) Release of the aspartyl protease cathepsin D is associated with and facilitates human breast cancer cell invasion. FASEB J 11: 785-792.

38. Ohkoshi M, Okuda S (2001) Growth inhibition of mouse skin tumor by serine protease inhibitor ONO-3403. Anticancer Res 21: 1803-1808.

39. Urade M, Komatsu M, Yamaoka M, Fukasawa K, Harada M, et al. (1989) Serum dipeptidyl peptidase activities as a possible marker of oral cancer. Cancer 64: 1274-1280.

40. Verspaget HW (1998) Proteases as prognostic markers in cancer. BMJ 316: 790-791.

41. Lehne G (2000) P-glycoprotein as a drug target in the treatment of multidrug resistant cancer. Curr Drug Targets 1: 85-99.

42. Walsh N, Kennedy S, Larkin AM, Tryfonopoulos D, Eustace AJ, et al. (2010) Membrane transport proteins in human melanoma: associations with tumour aggressiveness and metastasis. Br J Cancer 102: 1157-1162. 